ISTVÁN GYARMATHY1,2, TAMÁS KOROMPAI ${ }^{3,2}$, RICHÁRD NOVÁK ${ }^{3,2}$, JÁNOS VARGA², MIKLÓS DOMBOS ${ }^{4}$

\title{
INVESTIGATION OF INSECT ATTRACTION EFFECT OF LAMPS WITH DIFFERENT COLOR TEMPERATURES
}

\author{
${ }^{1}$ Hortobágy National Park Directorate, Debrecen, Hungary, ${ }^{2}$ Eszterházy \\ Károly University, Institute of Biology, Eger, Hungary, ${ }^{3}$ Bükk National \\ Park Directorate, Eger, Hungary, ${ }^{4}$ Institute for Soil Sciences and Agricul- \\ tural Chemistry, Budapest, Hungary
}

E-mail: gyarmathyistvan@hnp.hu

\begin{abstract}
The aim of our research is to analyze the ecological effects of light sources of different colors. Quantity and size of arthropods captured by light traps are continuously recorded by the Zoolog auto sampler, along with temperature and humidity data. By statistically analyzing large amounts of data, it is possible to estimate the amount of biomass removed by different types of lamps from their habitat, to monitor daily and longer-term activity changes, and to analyze the attractiveness of LEDs of different color temperatures. This will also allow conclusions to be drawn for conservation management.
\end{abstract}

Keywords: light pollution, remote sensing, colour temperature, light trap, conservation management 


\section{ISTVÁN GYARMATHY1,2, TAMÁS KOROMPAI ${ }^{3,2}$, RICHÁRD NOVÁK ${ }^{3,2}$, JÁNOS VARGA², MIKLÓS DOMBOS ${ }^{4}$ \\ KÜLÖNBÖZŐ SZÍNHŐMÉRSÉKLETŰ LÁMPÁK ROVAR- VONZÓ HATÁSÁNAK VIZSGÁLATA}

${ }^{1}$ Hortobágyi Nemzeti Park Igazgatóság, Debrecen, ${ }^{2}$ Eszterházy Károly Egyetem, Biológiai Intézet, Eger, ${ }^{3}$ Bükki Nemzeti Park Igazgatóság, Eger,

${ }^{4}$ Agrártudományi Kutatóközpont, Talajtani Intézet, Budapest

\section{Összefoglalás}

Kutatásunk célja a különböző színhőmérsékletű fényforrások ökológiai hatásának elemzése. A fénycsapdák által bevonzott ízeltlábúak mennyiségi és méretadatait a Zoolog automatikus mintavevő folyamatosan rögzíti, együtt a hőmérséklet- és páratartalom-adatokkal. Így nagy mennyiségű adat statisztikai elemzésével lehetőség nyílik a különböző típusú lámpák által élőhelyükről kivonzott biomassza mennyiségének becslésére, illetve a napi és hosszabb távú aktivitásváltozások nyomon követésére és a különböző színhőmérsékletű LED-ek attraktivitásának elemzésére. Ez lehetővé teszi a természetvédelmi kezelést elősegítő következtetések levonását is.

Kulcsszavak: fényszennyezés, távérzékelés, színhőmérséklet, fénycsapda, természetvédelmi kezelés 


\section{Introduction}

Photosensitivity is essential for a wide range of animals, especially flying insects. Insects are sensitive to a wide spectrum of light, from ultraviolet (UV) invisible to humans to red. Their orientation, daily activity, and annual rhythm are highly dependent on lights and natural light patterns.

Photosensitivity also plays an important role in nutrition and reproduction. Insects move toward the source of illumination when exposed to light, but light can also deflect, repel them (positive or negative phototaxis), increase or decrease their activity (BERTHOLF, 1940). Increasing outdoor lighting today poses a significant conservation problem due to its impact on insects. Luminaires used in public lighting practically act as light traps. In dark areas, a light source can attract up to 2,000 to 11,000 insect specimens overnight. The amount of insects removed from their habitat by artificial lights - and mostly killed - is enormous: in a study in the US, a single light trap caught $36.8 \mathrm{~kg}$ (about 85 million individuals) of mud mosquitoes in one night (RICH AND LONGCORE, 2006)

During a collection in a large Hungarian city, in which insects were trapped along illuminated wall surfaces, during the two hours daily collecting program in 50 times 17,400 specimens of 148 species of ground beetles (Carabidae) were captured all together. It was about $20 \%$ of all the captured insects. Particular interest is that this about ten square meters wall surface also attracted species from saline habitats of 25-30 km distance (КӧDöвöcz, 2018)!

Even within a short period of time, luminaires or illuminated surfaces that cause significant light pollution may concentrate insects to such an extent that there are not enough insects left in darker habitats as a food source for predators. This effect or process - together with the fragmentation effect of light pollution - can result in a significant transformation of the species pool (and thus the ecosystem as a whole) relatively quickly and over a large area (DAvIES et al., 2012).

We can assume that the decreasing number of insects detected all over Europe can partly be caused by light pollution.

All this information goes beyond the facts of each individual species and sites, highlighting the evidence that the worldwide increasing illumination causes intensive interference with the animal species, which has strong effects on living communities, and thus the entire ecosystem can be damaged.

This is why it is important to identify the types of light sources and lighting modes that cause the least damage to the natural environment, including the insect world, which plays a key role in the food chain.

Different responses to illumination are related to different intensities and polarizations of light. Insects also have color perception and are particularly sensitive to shorter wavelength (blue) regions of the visible spectrum and UV light (AshraQ et al., 2005).

A similar pattern of insect orientation toward light has been observed in several other studies. (JESSICA and CuRTIS 2001, ThomAs 1996). The results show 
that most of the orders are attracted to blue and UV lights. If we want to find the reasons for this attraction, we have to examine the physiological roots as well as the behavior of insects.

The attraction is merely due to shorter wavelengths (higher frequency) while the effect of red light is less significant, which makes it harder for the insects to detect. Insects have three special eyes, called ocelli, with the specific job of identifying light and not the movement. For the ocelli it seems that shorter wavelengths are easier to detect.

Many insects forage at twilight when blue light dominates the irradiance spectrum of the sky. Under starlight, irradiance spectra are 'red-enhanced' and strongly influenced by the presence or absence of the moon. Blue wavelengths become dominant as the solar elevation angle decreases and the Sun disappears below the horizon. For 1-2 hours between sunset and astronomical twilight, blue-shifted twilight offers a constant polarization pattern in non-cloudy skies that provides insects with orientation clues. (CRONIN et al., 2006)

As it was mentioned earlier, arthropods - for example, in the evening, night-active moths and other insects - are particularly sensitive to cold (white, blue and ultraviolet) radiation: as the eyes of butterflies $380-400 \mathrm{~nm}$ are the most sensitive, while less sensitive to the longer-wavelength spectral regions. It explains that the attracting effect of different light sources depends on the spectral composition. Therefore blue or cool white light-emitting metal halide lamps or LEDs have a 6-10 times higher attractive effect for moths than sodium lamps with longer wavelength (warm white or yellow) light. So for the butterflies the LED with cold light seems up to 10 times brighter than the yellow sodium lamps with the same radiance! (HUEmer et al., 2010)

Based on the above knowledge, we wanted to test the insect attraction of different types of light bulbs widely used in public lighting. We assumed that the color temperature -and in a second stage, the spectral composition- of lamps is more important than the brightness of lamps. To prove this, we launched a research program using traps applying light sources with different color temperatures and light intensities. We also used a novel automatic remote sensing method to count fallen insects: the ZooLog sampling system, an improved version of the Edapholog monitoring system. (Dombos et al. 2017)

\section{Material and methods}

We used four Jermy type light traps fitted with lamps of different color temperatures. 1.: $4000 \mathrm{~K}, 3100$ Lumens mercury lamp (ML). It was also used in old street lighting systems and light traps. 2.: $4000 \mathrm{~K}, 3040$ Lumens compact fluorescent lamp (CFL). Currently it is the most widely used lamp type in street lighting. 3.: $4000 \mathrm{~K}, 2450$ Lumens LED lamp; this is most commonly used in street lighting upgrades. 4.: $2700 \mathrm{~K}, 2450$ Lumen LED lamp; usually this is recommended for nature-friendly lighting. 
Automatic counting sensors were installed under the Jermy type light traps, which provide the following data via mobile internet connection to a central server: number of captured individuals, detection time, current temperature and humidity, and value correlating with body size. (Dомвоs et al., 2018; www. zoolog.en)

Monitoring program started with calibration. The number of insects was manually counted and compared with the results of the probes. Than we calibrated the probes using machine learning. The traps were placed in the Botanical Garden of the Eszterházy Károly University in Eger, well separated from each other (Fig. 1). We started the calibration in the end of 2019. The actual research was launched in April 2020 and is planned to continue throughout the year, with continuous on-line measurement lasting from twilight to dawn daily.

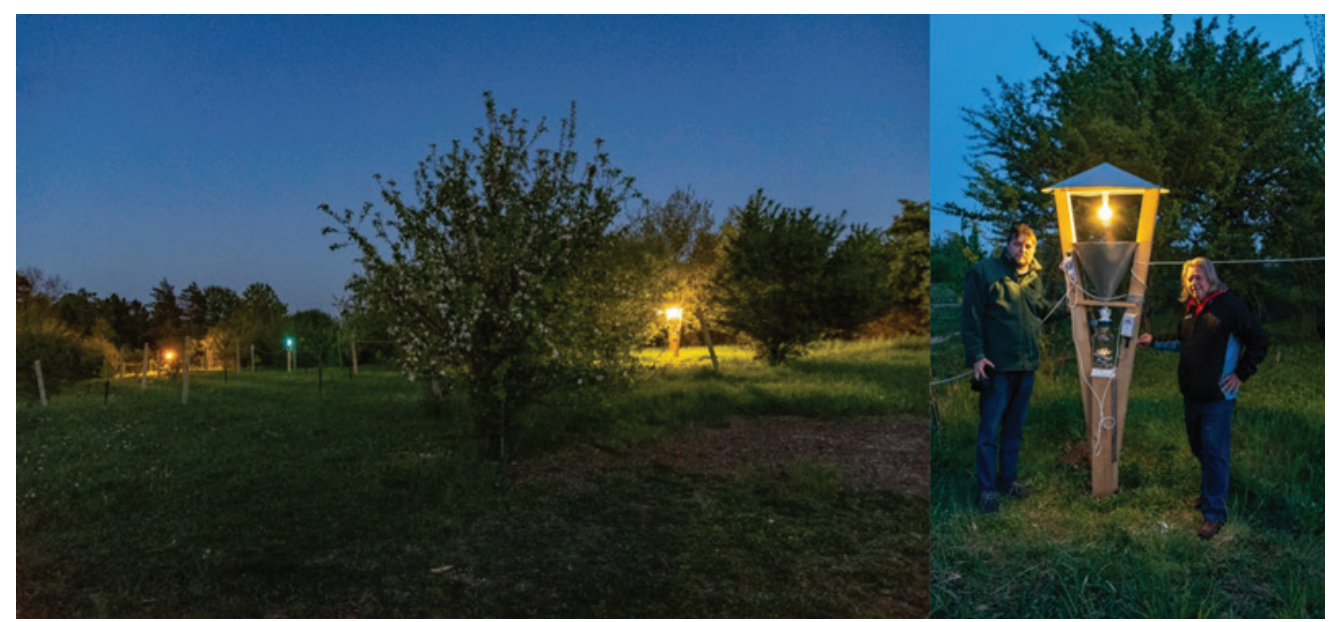

Figure 1. The Jermy traps with different lamp types and the trap with yellow LED. Source: image taken by Richárd Novák (2020)

Our newly developed monitoring system uses an IR (infrared) sensor ring to detect trapped insects. (BALLA et al. 2020) The principle of detection is essentially a light gate that operates in the near-infrared range to reduce ambient light interference. As an infrared light source, we use a TSAL6200 type LED with a maximum radiation of $940 \mathrm{~nm}$. A photodiode type BPV10NF is used as the infrared sensor in "photovoltaic" mode.

Accuracy is ensured by a model made in a 3D design program and then a workpiece made from this model using a high-resolution resin 3D printer as a support and positioning frame. 3D printing has made it possible to trap the entry and exit of unwanted lights due to scattering on the transmitter and receiver side with a formal solution, thus reducing the sensitivity of the device to ambient light noise (Fig. 2). 

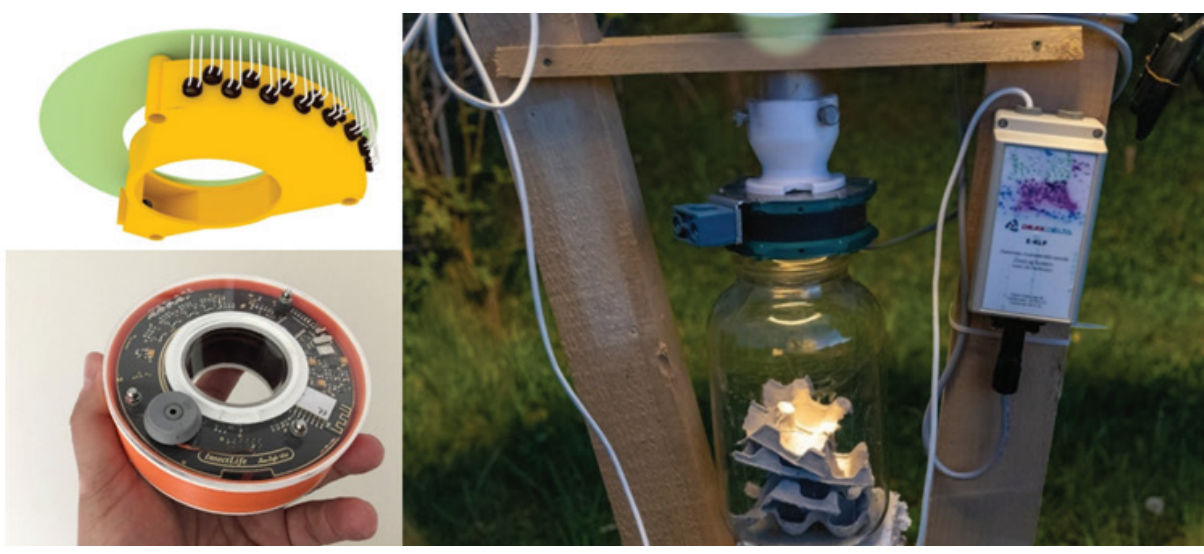

Figure 2. Zoolog ring and data collector, and as it is attached to the Jermy trap. Source: zoolog.hu (2020), image taken by István Gyarmathy (2020)

The probe transmits the data collected to a central server database using a GSM / GPRS modem (Fig. 3).

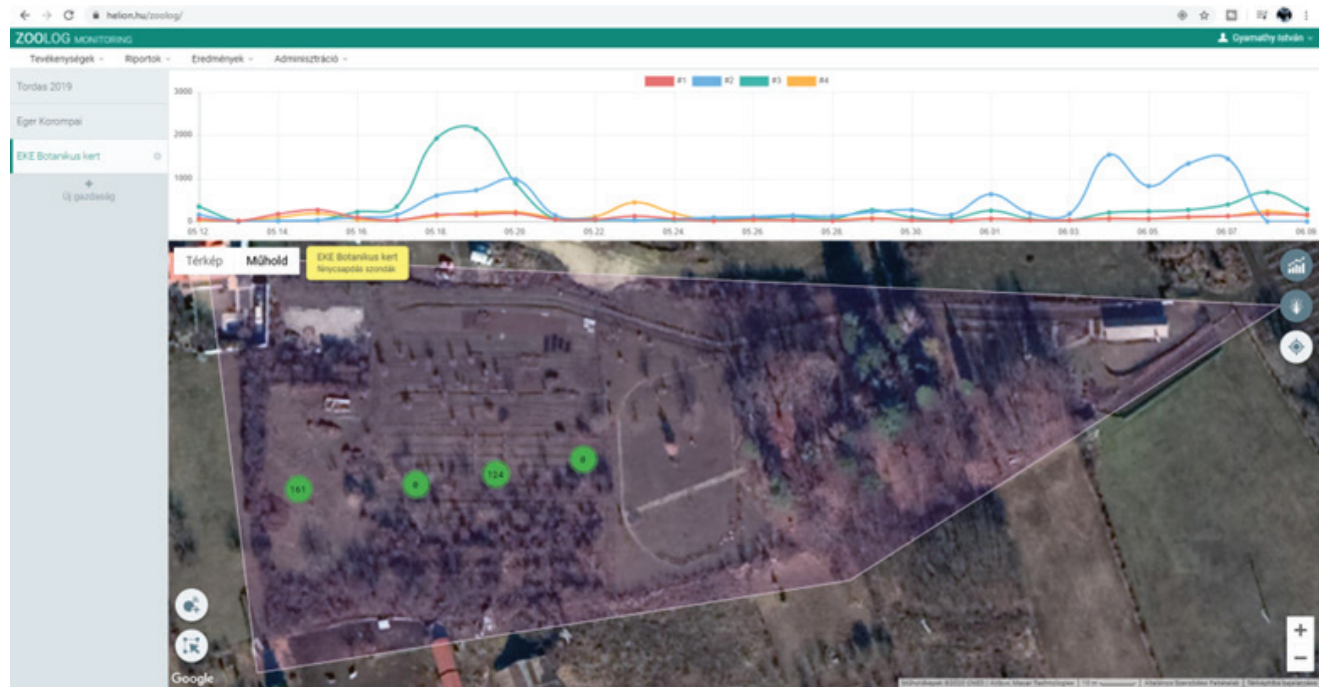

Figure 4. Zoolog data collector's results can be seen online (on the image the traps distribution can be seen too in the Botanical Garden) . Source: https://helion.hu/zoolog/ (2020) 


\section{Results}

Using the data gained by the automatic detection we were able to count the average numbers of the nighttime collection of the different traps.

Our first results prove our hypothesis that color temperature plays an important role in insect attraction of different type streetlamps. Our results can be seen in the diagram below (Fig. 4).

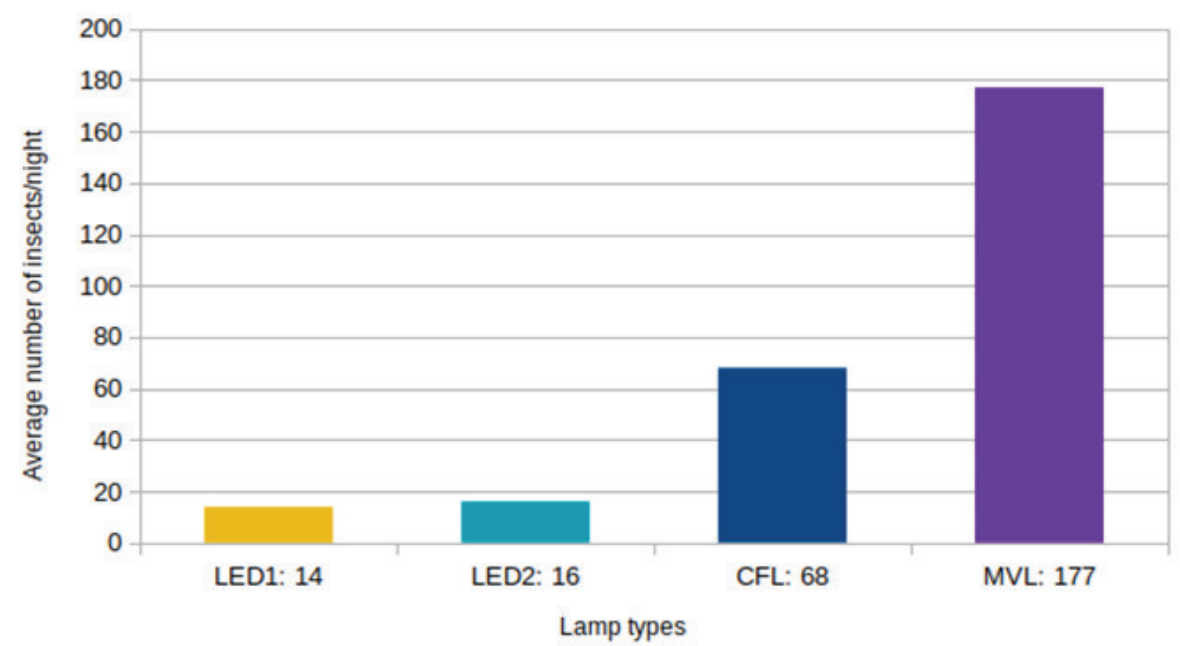

Figure 4. Results according to different lamp types: average number of captured insects/night. LED1 2700K, 2450L; LED2: 4000K, 2450L; CFL: 4000K 3040L; ML:4000K, 3100L)

The collected samples were also measured with a laboratory balance. The diagram below (Fig. 5) shows the average dry weight of biomass attracted per night by each lamp type. It can be seen that the measured biomass quantity shows a pattern, similar to Fig. 4. There is no linear correlation because a number of small insects (e.g. Diptera) can weight less than one big beetle (e.g. Coleoptera). 


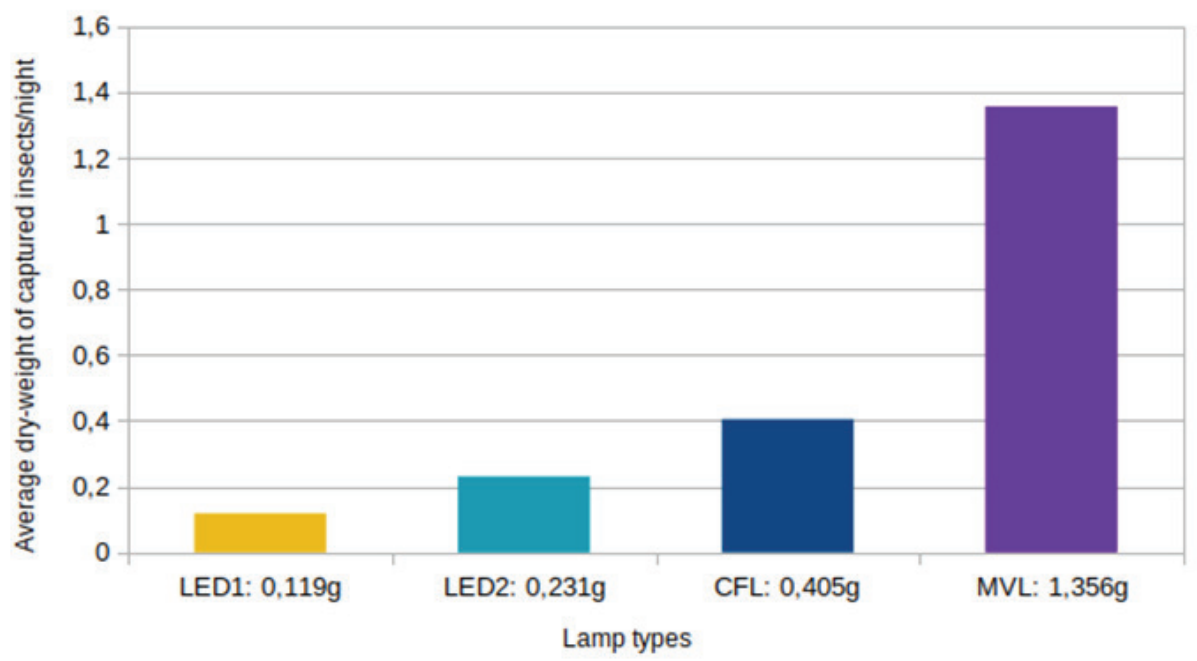

Figure 5. Results according to different lamp types: average dry-weight of captured insects/night. LED1 2700K, 2450L; LED2: 4000K, 2450L; CFL: 4000K 3040L; ML:4000K, 3100L)

The image below shows a sample collected during one night. The results mentioned above can be seen well here (Fig. 6).

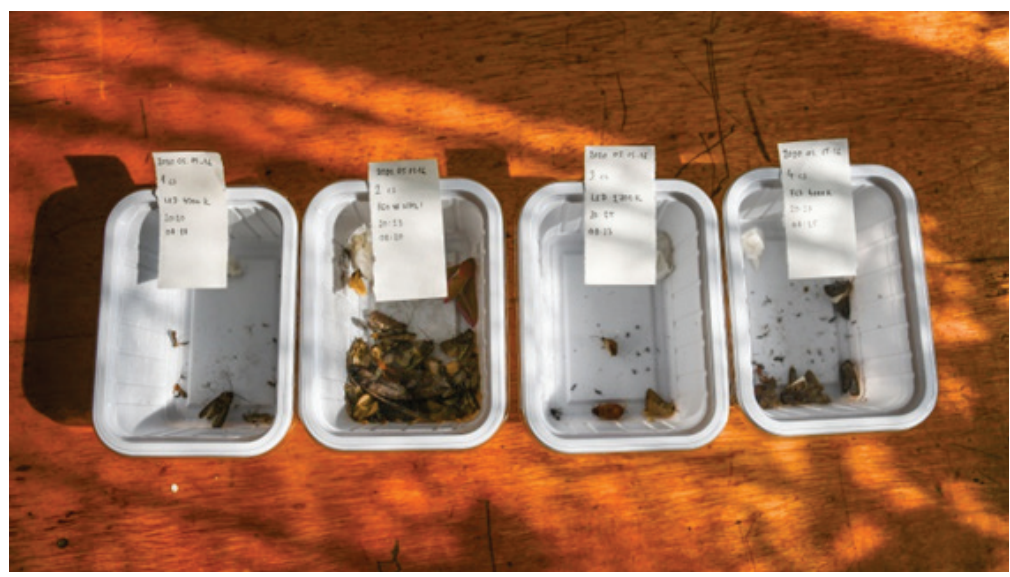

Figure 6. The samples collected by the traps during one night: from left: LED $4000 \mathrm{~K}, \mathrm{ML}$ 4000 K, LED 2700 K, CFL 4000 K. Source: image taken by István Gyarmathy (2020).

At the same time it has become clear that the light intensity is an efficient factor too. The brightest lamps with the highest light intensity but same color temperature captured more insects. The less attractive lamp in our experiment is the yellow LED with $2700 \mathrm{~K}$ and 2450 lumen. To our surprise, the $4000 \mathrm{~K}$ LED 
lamp captures only slightly more insects. There is a significant increase with the $4000 \mathrm{~K} 3040$ lumen compact fluroescent-lamp, and obviously the most attractive is the mercury vapour lamp with $4000 \mathrm{~K}$ and 3100 lumen.

We have only limited data as the research has started recently. We plan to continue our program gathering more data for more accurate results. As there is a quite big variability amoung the same $4000 \mathrm{~K}$ color temperature lamps, we plan to make a spectral analysis of the lamps to identify the most attractive spectra. We assume that the ML and the CFL spectra should contain more blue components than the LEDs have. We also plan to track changes in daily and longer-term activities of the insects.

\section{Conclusion}

Automatic data collection allows large amounts of data to be collected, properly processed and interpreted. Testing of the system began at the end of 2019, and the four lamp experiment started in April 2020. Our preliminary results have already demonstrated that the use of an automated probe with continuous insect trapping allows the collection of large amounts of statistically analyzable data under different color temperature illuminations. This provides an opportunity to estimate the amount of biomass removed from their habitat, and to analyze the attractiveness of light sources with different spectral distributions.

The spectral distribution plays an important role in the attraction of different insects. Our experiment proved that yellow light is less attractive than white-blue light. Light intensity is also important, less is better for conservation purposes.

The results provide an opportunity to select light sources with the least negative impact on wildlife in the future for outdoor lighting near natural and protected natural areas.

\section{Acknowledgement}

The project is supported by the European Union and co-financed by the European Social Fund (Grant no. EFOP-3.6.2- 16-2017-00014; Development of international research environment for light pollution studies). We would also like to thank Deák Delta Ltd. for providing the samples and for their assistance in their commissioning. 


\section{References}

AshfaQ, M., Khan, R., Ashan, M., Rasheed, F. (2005). Insect orientation to various color lights in the agricultural biomes of Faisalabad. Journal Pak. Entomol. VL-27

BABBiE, E. (1973): Survey Research Methods. Wadsworth Pub. Co. 744 p.

Balla E, Flórián N, Gergócs V, Gránicz L, Tóth F, Németh T, Dombos M. (2020). An Opto-Electronic Sensor-Ring to Detect Arthropods of Significantly Different Body Sizes. Sensors, 20(4), 982. DOI: https://doi.org/10.3390/s20040982

Bertholf, L. M. (1940): Reactions to Light in Insects. Bios.1940. 11, 39-43.

Cronin T. W., Warrant E. J., Greiner B. (2006). Celestial polarization patterns during twilight. Applied Optics. 45, 5582-5589. DOI: https://doi.org/10.1364/ AO.45.005582

Davies, T. W., Bennie, J., Gaston, K. J. (2012). Street lighting changes the composition of invertebrate communities. Biology Letters 8(5), 764-7. DOI: https://doi. org/10.1098/rsbl.2012.0216

Dombos, M., Kosztolányı, A., Szlávecz, K., Gedeon, C., Flórián, N., Groó, Z., Dudás, P., BÁnszeGl, O. (2017). Edapholog monitoring system: automatic, real-time detection of soil microarthropods. Methods in Ecology \& Evolution 8, 313-321. DOI: https://doi.org/10.1111/2041-210X.12662

Dombos, M., Flórián, M., Gergőcs, V., Schellenberger, V., Haszon, B., Nagy, A. (2018). Ízeltlábúak automatikus detektálási problémái és megoldásai terepi vizsgálatokban. 11. Magyar Ökológus Kongresszus. Absztraktkötet Nyíregyháza, Magyarország, Magyar Ökológusok Tudományos Egyesülete, pp. 30-30.

Huemer, P., Kühtreiber, H., Tarmann, G. (2010). Anlockwirkung moderner Leuchtmittel auf nachtaktive Insekten -Ergebnisse einer Feldstudie in Tirol, Kooperationsprojekt Tiroler Landesumweltanwaltschaft, Innsbruck

JessicA, P., CURTIS, A. (2001). Insect Response to different wavelengths of light in New River State Park, Ashe County, North Carolina, USA.

Köрöвöcz, V. (2018): Fényen gyűjtött futóbogarak (Coleoptera: Carabidae) a debreceni Malompark Bevásárlóközpontnál, 2000 és 2018 között. Folia Historico-Naturalia Musei Matrensis 42, 71-82

Rich, C., Longcore, T. (2006). Ecological Consequences of Artifical Night Lighting, Island Press, Washington

Thomas, A. W. (1996). Light trap catches within and above the canopy of a northeastern forest. Journal of Lepidopterist's Society 50, 21-45. 